\section{PEER-REVIEWED ARTICLE}

Food Protection Trends, Vol 41, No. 2, p. 216-231 Copyright 2021 , International Association for Food Protection 2900 100th Street, Suite 309, Des Moines, IA 50322-3855
Pei Liu* and Soojin Lee

Hospitality Management, University of Missouri-Columbia, Gentry Hall, Columbia, MO 65201, USA
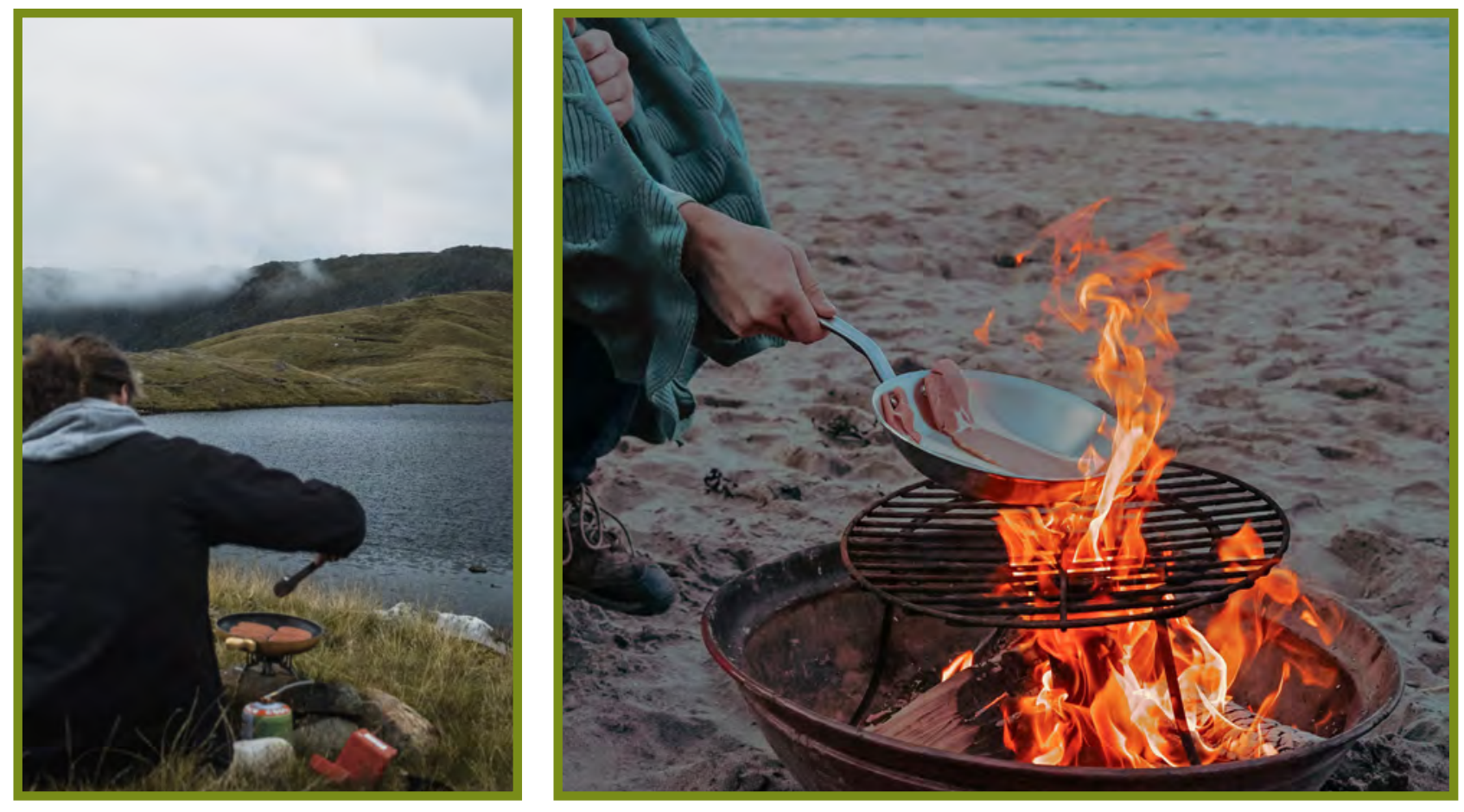

\title{
Food Safety Knowledge and Self-Reported Practice among Campers in the United States
}

\section{ABSTRACT}

Food safety during camping is an important part of outdoor safety and a healthy eating experience. A significant number of foodborne illness outbreaks occurring at campsites in the United States could be due to the lack of food safety training for campers. Although camping is growing in popularity in the United States, topics regarding camping food safety have been underresearched. The present study focused on assessing food safety knowledge and self-reported practices in a sample of 286 campers in the United States via an online survey. Cross-contamination and time and temperature were the two top food safety categories, whereas groups at greatest risk, risky foods, and common pathogens were the least important at-risk categories. Independent $t$-tests and one-way analyses of variance indicated that significant differences in food safety knowledge exist according to gender, ethnicity, and education. Food safety knowledge did not differ among age groups; younger campers knew more about the time and temperature category than did older campers. Pearson's correlation analysis revealed a significant correlation between food safety knowledge, previous training, and self-reported practices. Nevertheless, camping experiences and food service work experience did not increase food safety knowledge. These results suggest that camping food safety educators should provide training through demonstration-based learning to better improve campers' safe food handling practices, which would also result in prevention of foodborne illness outbreaks during camping outings.

\section{INTRODUCTION}

Foodborne disease causes approximately 48 million illnesses, 128,000 hospitalizations, and 3,000 deaths each year in the United States as estimated by the U.S. Food and Drug Administration (38) and the Centers for Disease Control and Prevention (CDC) (7). A foodborne outbreak is defined as two or more people becoming sick from a contaminated food or beverage (28). Of the 46,024 foodborne outbreaks reported from 1999 to 2017,369 were associated with food served at campsites, including 12,126 individual illnesses, 213 hospitalizations, and one death 
(5). A histoplasmosis outbreak occurred at a Louisiana campsite among a group of campers in November 2018 (6). The number of foodborne illness outbreaks has increased significantly from 8 in 1997 to 40 in 2017 (6). In 2018, a total of 44 outbreaks were reported, the most foodborne illness outbreaks during the past 20 years (6). In response to this trend, people may become concerned about how to handle food safely in camp settings. In 2020, The Washington Post (4) announced that a norovirus infection outbreak had hit tourists and campers at Yosemite National Park. Norovirus infection occurs through direct contact with an infected individual or consumption of contaminated food or water (4). About 170 people who worked or camped at the park suffered from a gastrointestinal illness, with vomiting and diarrhea.

The term "camping" refers a range of activities and approaches to outdoor accommodations (8). According to a recent statistic from the North American Camping Report (18), approximately 40 million Americans, about $14 \%$ of the U.S. population, went camping in 2018. Since 2014, the number of households that camp each year has grown by more than 7 million and the percentage of campers who camp more than three times per year has increased by $72 \%$ (19).

Food safety education and awareness when camping is important because of the many areas where food can become contaminated and cause foodborne illnesses. With the increased use of motor homes and recreational vehicles (RVs), a variety of foods can be transported to the campground and cooked carefully because of the access of domestic equipment for safe food preparation (8). However, because most people prefer to camp during the summer, the high temperatures of that season can increase the risk of foodborne illnesses (36) as has been confirmed by the CDC (7): from 1998 to 2017, 239 of 369 foodborne illness outbreaks occurred in June and July. The number of foodborne illness outbreaks at camps also has increased every year since 1997 (30). Therefore, camper education to prevent foodborne outbreaks should be focused on improving food safety knowledge and encouraging safe food-handling practices. In another study, the number of outbreaks was reported to have increased dramatically in camp settings from 0 in 1997 to 26 in 2017 due to person-to-person crosscontamination (6). Considering this trend, it is critical to determine the current food safety knowledge and practices among campers in the United States. The purpose of this study was to evaluate the food safety knowledge and practices among campers in the United States. The results of this study will raise awareness among the public regarding the food safety risks associated with camp settings.

\section{Camping in the United States}

The United States is considered the home of outdoor activities - including the deserts of Utah, the mountains of Colorado, and along the west coast in Washington State (1). People also camp at national parks and along the east coast $(1,3)$. Outdoor activities maintain their popularity in North America and many other regions. People like outdoor activities and utilize various accommodations while seeking to relax and rejuvenate (1). Because outdoor activity can improve a person's psychological well-being, people who frequently enjoy outdoor activities perceive themselves to be heathier than people who do not (11). The popularity of outdoor activities also is a response to the changes in lifestyles in the United States $(17,27)$. When more leisure time is available, people tend to notice the lack of activity in their lives. The popularity of outdoor activities is higher in more developed countries, such as the United States, because society is more likely to react to human nature and human needs (17). In the United States, more than 40 million people enjoy camping each year (8). Another reason for this popularity is that camping is an activity for which accommodations can be comparatively inexpensive (14). Jirasek, Roberson, and Jiraskova (16) described camping as a way of developing rapport and bonding within the family. The American Camper Report (8) revealed that nearly $80 \%$ of people in the United States camp in tents. Camping allows people to approach nature, which is often seen as beneficial for health (42).

Camping includes adventurous activities such as hiking, trekking, rafting, fishing, and other outdoor activities (1). Zhong, Lin, Huang, Chen, and Chien (42) found that campers' desire to improve their health and the novelty of services appeared to have a greater impact on their satisfaction. According to Statista (32), nearly $22 \%$ of Americans 30 to 49 years of age went camping in 2018. A little more than $20 \%$ were 18 to 29 years of age, and about $19 \%$ were 50 to 64 years of age. Among young people from 6 to 17 years of age, approximately 10 million participated in camping from 2006 to 2017 . As of $2017,41.8$ million people in the United States spent almost $\$ 3$ billion on camping equipment, as indicated in the North American Camping Report (19), and the estimated total number of camping households was nearly 78 million, an increase of 7 million since 2014. These statistics support the high prevalence of camping in the United States. Over half of North Americans occasionally camp to escape their daily routine and seek relaxation $(31,32)$. Despite the popularity of camping, however, limited research has been conducted on food safety practices among campers in the United States (11).

\section{Food safety during camping}

In the United States, an estimated one in every six people is affected by foodborne disease, with 3,000 deaths $(7,28)$. Some early researchers stated that because little attention had been given to the promotion of hygiene practice in the home, a reliable hygiene policy should be developed for the home $(13,41)$. The contamination and spread of 
bacteria and viruses happens rapidly when handling, chilling, cooking, and cleaning foods, and the causes of foodborne illnesses in the home can be difficult to determine because food is consumed across different settings (13). In some studies, experiments and observations have been used to assess food safety behaviors in the home $(25,41)$. Although the majority of study participants used safe cooking practices in the home setting, some did not follow safe practices concerning reheating and stored food at improper temperatures. Researchers also determined that indirect and direct cross-contamination while preparing foods was the most significant unsafe practice (41). Wills, Meah, Dickison, and Short (40) argued that foodborne illness is a public concern and that it is caused by food prepared and cooked at home. Despite this concern, U.S. consumers perceive their personal risk associated with home cooking as low (24). Due to these perceptions and optimistic bias, consumers believe they are in control of any exposure to foodborne illness $(22,23)$. However, Neff et al. (26) found that consumers misunderstand the meaning of food date labels, which leads to frequent food discards (26). As these findings indicate, education is needed to improve consumers' food safety knowledge in the United States.

According to a recent study on consumer food safety, consumer perceptions of food safety differ among individuals $(10,39)$. U.S. consumers make decisions based on their past experience, knowledge, and convenience when handling foods (22). For this reason, consumers perceive different levels of risk associated with foods. In the United States, more than half of foodborne illnesses are associated with foods prepared in the home (22). Food safety knowledge, attitudes, and behaviors differ across demographic and socioeconomic groups $(17,41)$. Terpstra, Steenbekkers, Maertelaere, and Nijhuis (33) found that older people lacked food safety knowledge about such issues as food storage times. Evans and Redmond (9) found that older adults believed they were at lower levels of risk than were other individuals, suggesting perceptions of personal invulnerability. Thus, older people may be more likely to practice unsafe food handling, food consumption, and cooking behaviors (34). Improper food storage leads to cross-contamination, and the consequence of handling and consuming contaminated food may be the increased likelihood of foodborne illnesses (41). Because poor food handling practices may result in foodborne outbreaks (34), it is essential to educate and inform consumers about proper food handling practices. One group of researchers noted no relationship between food safety knowledge and practice; a significant number of study participants reported unsafe food practices even though they had a high awareness of food safety (26). Thus, actual food safety practices may not be effectively transferred from food safety knowledge.

According to the American Camp Association (ACA) (2), a camp may be in a rural location where an ambulance might be restricted from easily access in a timely manner. As a result, prior to going camping, campers need to ensure available transportation and prepare for necessary medications in case of emergencies due to foodborne illness. In addition, campers should plan what equipment will be used during the camping trip (35). The U.S. Department of Agriculture (USDA) (35) also recommended bottled water; otherwise, water should be boiled before drinking. The number of foodborne illness outbreaks at camps increases every summer (30). Although most cases are minor, they can turn into serious outbreaks. Schirick (30) stressed the importance of also educating camping staff members to enhance the food safety knowledge and follow safe food handling practices to effectively prevent foodborne outbreaks. The results of their investigation found that the number one cause of foodborne illness outbreaks among campers was cross-contamination, especially when viruses transfer from person to person (7). Therefore, more attention should be given to educating campers on how to prevent cross-contamination during outdoor activities. Additionally, campers might suffer from a food allergy if cross-contact is not prevented. The ACA $(2,3)$ emphasized that campers are twice as likely to become ill due to foodborne diseases as opposed to getting physically injured. For this reason, the USDA (35) suggested that campers should keep all perishable foods at the appropriate hot or cold temperatures. More specifically, food safety guidelines suggested that campers bring frozen gel packs to keep meals cold. Bacteria are likely to grow rapidly at temperatures between 40 and $140^{\circ} \mathrm{F}$ on perishable foods because this range is considered the temperature danger zone (37). Cross-contamination can be best prevented by washing hands before and after handling food (37). The juices from raw poultry and other meats can also cause cross-contamination (7). For this reason, raw foods should be placed in plastic bags. A food thermometer is an important piece of camping equipment used to determine when cooked food is safe to consume (37). It is critical to understand that a food thermometer is the only way to ensure that foods are adequately cooked and safe to consume (35, 37). Nevertheless, training materials such as those that are available through the ACA and USDA do not seem effective in preventing foodborne outbreaks among campers. In fact, the increasing number of annual foodborne illness outbreaks indicated a gap between the food safety guidelines and the current knowledge and practices among U.S. campers.

\section{MATERIALS AND METHODS}

Approval to use human subjects in this research was obtained from the University Institutional Review Board prior to the initiation of research.

\section{Instrument and validation}

Based on the literature review, a survey questionnaire was developed that comprised three sections. The first section 
included demographic questions addressing gender, age, ethnicity, educational level, household income, past camping experiences, and camping frequency. The second section tested the participants' food safety knowledge about crosscontamination, hygiene practices, food cooking temperatures, and common sources of foodborne outbreaks. The 34 food safety knowledge questions were from five categories: crosscontamination and hygiene practices, times and temperatures, foodborne risk sources, groups at greatest risk, and common pathogens. The cross-contamination and hygiene category consisted of nine questions related to preventing foodborne illness by washing hands and handling foods properly. The time and temperature category contained 12 questions about these two important factors. The foodborne risk category contained three questions that asked respondents to choose foods that increase the risk of foodborne disease. The groups at greatest risk category contained two knowledge questions related to identifying groups of individuals who are particularly vulnerable to foodborne illness. The eight questions about common pathogens also were asked. For these 34 questions, one point was given for each correct answer and zero points were given for each incorrect answer. The percentage of correct answers was calculated for each participant. The third section was designed to measure the participants' self-reported food safety practices. For these nine questions, answers were based on a 5-point Likert scale from 1 (almost never) to 5 (always). The complete questionnaire was reviewed and validated by five individuals from the restaurant industry and experts in the area of food safety. A pilot study was completed by invitation through a listserv at the university $(n=30)$. The results of the pilot study were used to evaluate the internal consistency of the questionnaire's constructs based on Cronbach's alpha $(\alpha \geq 0.7)$. Participants provided feedback about the clarity of the directions so the questionnaire could be appropriately revised.

\section{Study participants and data collection}

The survey questionnaire with validated questions was developed by means of a commercial survey company web site (SurveyMonkey, https://www.surveymonkey.com/). The Web site provides diverse question forms and enables the design of complex questions such as a matrix question form. For data collection, Dynata (Plano, TX), a major market research company (formerly Research Now), was contacted to obtain access to a collection of online data concerning participants across the United States. This method of data collection provided a broader range of information about respondents' attitudes and opinions (21). Eligible participants were individuals $\geq 18$ years of age who had camped within the previous year in the United States.

\section{Data analysis}

The Statistical Package for Social Sciences for Windows v. 25.0 (IBM, Armonk, NY) was used to analyze the data. A descriptive statistical method was used to summarize the data and evaluate food knowledge scores. Pearson's correlation coefficient was used to understand the correlation between food safety knowledge scores and self-reported practices. A $t$-test was used to understand the affects of gender on food safety knowledge, differences in food safety knowledge, and the types of food safety practices among campers with foodborne illness experiences and past food handling experiences. One-way analyses of variance (ANOVAs) revealed possible differences in food safety knowledge across demographic variables.

\section{RESULTS}

\section{Participant demographics}

Of 286 respondents, nearly half (44.1\%) were 56 to 65 years of age, followed by participants 26 to 35 years of age (Table 1). More than half $(61.2 \%)$ of respondents were women. Most (87.1\%) of the study respondents identified as Caucasian, six (2.1\%) identified as Asian, two (0.7\%) identified as Native American, and three (0.1\%) identified as Hispanic. The education level was almost evenly distributed among respondents: some college education (27.3\%), a graduate or professional degree (24.8\%), a bachelor's degree (21.7\%), a high school diploma or GED (10.1\%), some graduate work or beyond (7.0\%), and less than a high diploma (0.7\%). About $21 \%$ of the participants reported having an annual income of $\$ 30,000$ to $\$ 70,000,15.7 \%$ had $<\$ 30,000,11.5 \%$ had $>\$ 110,000,11.2 \%$ had $\$ 70,000$ to $\$ 90,000$, and $4.9 \%$ had $\$ 90,000$ to $\$ 110,000$.

Excluding invalid answers, when asked about their food service experience, a majority of the study participants (199, $69.6 \%$ ) reported that they had not worked at any food service facilities in the past, and only $23.1 \%$ (66) had some kind of food service experience before being involved in camping activities. However, only 38 of those 66 had previously received food safety training (Table 1). Only 46 (16.1\%) of the 246 participants actually had experienced foodborne illness at a campsite. Participants were also asked about their sleeping accommodations while camping: $52.1 \%$ (149) camped in tents and $33.9 \%$ (97) stayed in an RV except for those who went for a 1-day trip. These findings were consistent with the information in the American Camper Report (8), which also indicated that a majority of campers in the United States camp in tents.

\section{Overview of food safety knowledge}

The correct responses within each knowledge category are summarized in (Table 2). Each correct response received one point. The total knowledge score was calculated by adding the points.

The majority of the respondents had a high level of knowledge as indicated by answers to questions related to cross-contamination and hygiene practices (mean score $=5.41$; standard deviation $[\mathrm{SD}]=1.86)$ and time 


\section{TABLE 1. Characteristics of participants $(n=286)$}

Variable

Age (yr)

\begin{tabular}{l}
\hline $18-25$ \\
\hline $26-35$ \\
\hline $36-45$ \\
\hline $46-55$ \\
\hline $56-65$ \\
\hline $66+$
\end{tabular}

\begin{tabular}{|c|c}
\hline 17 & 5.9 \\
\hline 8 & 2.8 \\
\hline 15 & 5.2 \\
\hline 36 & 12.6 \\
\hline 54 & 44.1 \\
\hline
\end{tabular}

Gender

Female

Male

\begin{tabular}{|l|l|}
\hline 175 & 61.2 \\
\hline 87 & 30.4 \\
\hline
\end{tabular}

Ethnicity

Non-Hispanic Caucasian

Asian, Pacific Islander

Native American (American Indian)

Hispanic, Latino

\begin{tabular}{|c|c|}
\hline 249 & 87.1 \\
\hline 6 & 2.1 \\
\hline 2 & 0.7 \\
\hline 3 & 0.1 \\
\hline
\end{tabular}

Education

$<$ High school or GED

High school or GED

Some college

Bachelor's degree

Some graduate, professional work or beyond

Graduate or professional degree

$\mathrm{N} / \mathrm{A}$

\begin{tabular}{c|c}
\hline 2 & 0.7 \\
\hline 29 & 10.1 \\
\hline 78 & 27.3 \\
\hline 62 & 21.7 \\
\hline 20 & 7.0 \\
\hline 71 & 24.8 \\
\hline 24 & 8.4 \\
\hline
\end{tabular}

Food service experience

\begin{tabular}{l|c|c}
\hline Yes & 66 & 23.1 \\
\hline No & 199 & 69.6 \\
\hline Household income & \multicolumn{2}{|l}{}
\end{tabular}

Household income

\begin{tabular}{l|c|c}
\hline$<\$ 30,000$ & 45 & 15.7 \\
\hline$\$ 30,001-\$ 50,000$ & 59 & 20.6 \\
\hline$\$ 50,001-\$ 70,000$ & 59 & 20.6 \\
\hline$\$ 70,001-\$ 90,000$ & 32 & 11.2 \\
\hline$\$ 90,001-\$ 110,000$ & 14 & 4.9 \\
\hline$>\$ 110,001$ & 33 & \multicolumn{3}{|c}{11.5} \\
\hline Food safety training & 38 & \multicolumn{2}{|c}{13.3} \\
\hline Yes & 227 & \multicolumn{2}{|c}{79.4} \\
\hline No & \multicolumn{2}{|c}{4} \\
\hline Foodborne illness at campsite & 46 & 16.1 \\
\hline Yes & 219 & 76.7 \\
\hline No & \multicolumn{2}{|c}{} \\
\hline
\end{tabular}




\section{TABLE 1. Characteristics of participants (n = 286) (cont.)}

Variable

Frequency

Percentage

Camp sleep arrangement

\begin{tabular}{l|c|c}
\hline RV & 97 & 33.9 \\
\hline Tent & 149 & 52.1 \\
\hline
\end{tabular}

\section{TABLE 2. Correct responses to food safety knowledge questions by variables}

\begin{tabular}{l|c|c}
\multirow{2}{*}{ Knowledge } & \multicolumn{2}{|c}{ Correct responses } \\
\cline { 2 - 3 } & No. & Percentage \\
\hline Time and temp. & 207 & 72 \\
\hline Cross-contamination & 175 & 61 \\
\hline Risky food & 168 & 59 \\
\hline Groups at greatest risk & 157 & 54 \\
\hline Common pathogens & 131 & 46 \\
\hline Common food sources & 83 & 29 \\
\hline
\end{tabular}

and temperature $($ mean $=8.51, \mathrm{SD}=1.73)$. Respondents could correctly indicate the best way to prevent foodborne illnesses. Generally, respondents were aware of safe ways to avoid cross-contamination factors, including physical contaminants, dish washing procedures, and hand washing. When asked about groups at greatest risk (mean $=1.10, \mathrm{SD}$ $=0.70)$, foodborne risk sources $($ mean $=1.34, \mathrm{SD}=$ $0.78)$, and common pathogens (mean $=3.86, \mathrm{SD}=1.88$ ), respondents were least likely to answer correctly. They also lacked knowledge regarding groups of people who are particularly vulnerable to foodborne illnesses, sources that increase the risk, and the most common food pathogens. Because issues in these three categories were frequently misunderstood by campers, these categories should be given more attention than the other knowledge categories when designing educational materials.

The results of knowledge scores for each one of five knowledge categories are shown in Tables 3 through 7. First, the findings indicate that even though respondents knew about who should not prepare meals for others and when to wash hands, they did not know specific ways of practicing food safety and the correct washing procedures for preventing cross-contamination. Second, although respondents generally knew how to store and refrigerate foods safely, they were less knowledgeable about storing foods at the correct temperature to avoid time or temperature abuse. Third, respondents were generally aware of situations that may increase the risk of foodborne illnesses. Fourth, regarding questions about the groups of people at greatest risk for foodborne illness, about half of the respondents properly identified which groups of people were more susceptible to food poisoning and the types of food that pose the greatest risk. Fifth, respondents believed that any foods being prepared at a campsite needed to be cooked thoroughly. However, relatively few respondents could identify foods associated with specific types of bacteria.

\section{Food safety knowledge and gender}

Food safety knowledge differed by gender (Table 8 ). Men $(n=87)$ and women $(n=175)$ differed significantly in their knowledge of food safety during camping $(t(260)$ $=-2.95, P<0.01)$. In general, female campers were more knowledgeable $(21.43 \pm 4.13)$ than male campers (19.86 \pm 3.89 ). Women more often identified groups of people who are more likely to be affected by foodborne illnesses.

\section{Food safety knowledge and previous training}

Previous food safety training experience had a significant effect on levels of food safety knowledge $(t(243)=2.46$, $P<0.05$ ) (Table 8). Respondents' level of knowledge related to food safety while camping was impacted by previous training experience. If food safety training for campers were 


\section{TABLE 3. Results from the cross-contamination prevention and disinfection procedures scale}

\begin{tabular}{|c|c|c|c|c|}
\hline \multirow{2}{*}{ Rank } & \multirow{2}{*}{ Questions } & \multirow{2}{*}{$\begin{array}{l}\text { Total } \\
\text { possible } \\
\text { score }\end{array}$} & \multicolumn{2}{|c|}{ Correct answers } \\
\hline & & & Mean & SD \\
\hline 1 & $\begin{array}{l}\text { To prevent foodborne illnesses, which of these individuals should not prepare food for } \\
\text { other people? (Check all that apply) } \\
\text { Answer: a person with diarrhea, a person with a fever, a person with a sore throat, a } \\
\text { person who has been vomiting }\end{array}$ & 4 & 3.23 & 1.20 \\
\hline 2 & $\begin{array}{l}\text { When preparing food, you should wash your hands after touching which of these? } \\
\text { (Check all that apply) } \\
\text { Answer: your face, fresh fruit, a pimple, clothing }\end{array}$ & 4 & 3.09 & 1.70 \\
\hline 3 & $\begin{array}{l}\text { After you have used a cutting board to slice raw meat, chicken, or fish and need to cut } \\
\text { other foods, which of these is the best way to prevent food poisoning? } \\
\text { Answer: Choice 4: wash the cutting board with hot soapy water and rinse or Choice 5: } \\
\text { set the cutting board aside and use a different cutting board to cut other foods }\end{array}$ & 1 & 0.80 & 0.40 \\
\hline 4 & $\begin{array}{l}\text { Which is the most hygienic way to wash your hands? } \\
\text { Answer: run water, moisten hands, apply soap, rub hands together for } 20 \text { s, rinse hands, } \\
\text { dry hands with air dryer or disposable paper }\end{array}$ & 1 & 0.76 & 0.43 \\
\hline 5 & $\begin{array}{l}\text { The best way to wash fresh fruits and vegetables is to wash them with: } \\
\text { Answer: cool running water }\end{array}$ & 1 & 0.75 & 0.43 \\
\hline 6 & $\begin{array}{l}\text { To prevent food poisoning, the best way to wash dishes is to: } \\
\text { Answer: Choice 1: wash and dry them in an automatic dishwasher or Choice } 3 \text { : } \\
\text { hand wash them right after the meal and then let them air dry }\end{array}$ & 1 & 0.69 & 0.47 \\
\hline 7 & $\begin{array}{l}\text { Which of the following cleaning procedures for cooking surfaces is most likely to } \\
\text { prevent foodborne illnesses? } \\
\text { Answer: wash with a detergent, rinse, then wipe with a sanitizing solution }\end{array}$ & 1 & 0.50 & 0.50 \\
\hline 8 & $\begin{array}{l}\text { If you have a sore on the back of your hand, should you prepare food for other people? } \\
\text { Answer: Yes, if you bandage the sore and wear a glove }\end{array}$ & 1 & 0.47 & 0.50 \\
\hline 9 & $\begin{array}{l}\text { When should cooking surfaces be washed, rinsed, and sanitized? } \\
\text { Answer: after each use, when you begin working with another type of food, at 4-h } \\
\text { intervals if the counter is in constant use }\end{array}$ & 1 & 0.31 & 0.46 \\
\hline Total & & 15 & & \\
\hline
\end{tabular}




\section{TABLE 4. Results from the safe time and temperature for cooking and storing food scale}

\begin{tabular}{|c|c|c|c|c|}
\hline \multirow{2}{*}{ Rank } & \multirow{2}{*}{ Questions } & \multirow{2}{*}{$\begin{array}{l}\text { Total } \\
\text { possible } \\
\text { score }\end{array}$} & \multicolumn{2}{|c|}{ Correct answers } \\
\hline & & & Mean & SD \\
\hline 1 & $\begin{array}{l}\text { When shopping for groceries, refrigerated foods should be placed in the cart: } \\
\text { Answer: at the very end of the shopping trip, just before checking out }\end{array}$ & 1 & 0.89 & 0.32 \\
\hline 2 & $\begin{array}{l}\text { All the following food items need to be refrigerated to prevent foodborne illnesses } \\
\text { EXCEPT: } \\
\text { Answer: open box of raisins }\end{array}$ & 1 & 0.87 & 0.34 \\
\hline 3 & $\begin{array}{l}\text { If a family member is going to be several hours late for a hot meal, how should you store } \\
\text { the meal to keep it safe until this person is ready to eat it? } \\
\text { Answer: store it in the refrigerator and reheat it when the person is ready to eat it }\end{array}$ & 1 & 0.87 & 0.33 \\
\hline 4 & $\begin{array}{l}\text { All foods are considered safe when cooked to an internal temperature of: } \\
\text { Answer: } 165^{\circ} \mathrm{F}\left(74^{\circ} \mathrm{C}\right)\end{array}$ & 1 & 0.86 & 0.43 \\
\hline 5 & $\begin{array}{l}\text { For ground beef to be safe to eat, it needs to be cooked until its internal temperature } \\
\text { reaches: } \\
\text { Answer: } 160^{\circ} \mathrm{F}\left(71^{\circ} \mathrm{C}\right)\end{array}$ & 1 & 0.75 & 0.43 \\
\hline 6 & $\begin{array}{l}\text { Which is the most accurate way to determine whether hamburgers are cooked enough } \\
\text { to prevent foodborne illnesses? } \\
\text { Answer: measure the temperature with a food thermometer }\end{array}$ & 1 & 0.73 & 0.44 \\
\hline 7 & $\begin{array}{l}\text { Which of the following methods is not acceptable for safely thawing a frozen roast for } \\
\text { immediate cooking? } \\
\text { Answer: leave it on the kitchen counter until it is thawed }\end{array}$ & 1 & 0.68 & 0.47 \\
\hline 8 & $\begin{array}{l}\text { Imagine that your electricity went off and the meat, chicken, and/or seafood in your } \\
\text { freezer thawed out overnight and food felt a bit warm. To prevent foodborne illnesses, } \\
\text { what should you do? } \\
\text { Answer: throw them away }\end{array}$ & 1 & 0.67 & 0.47 \\
\hline 9 & $\begin{array}{l}\text { What is the maximum temperature refrigerators or coolers should be to preserve the } \\
\text { safety of foods? } \\
\text { Answer: } 41^{\circ} \mathrm{F}\left(5^{\circ} \mathrm{C}\right)\end{array}$ & 1 & 0.66 & 0.48 \\
\hline 10 & $\begin{array}{l}\text { To prevent foodborne illnesses, how long should leftover foods be heated? } \\
\text { Answer: until they reach } 165^{\circ} \mathrm{F}\end{array}$ & 1 & 0.58 & 0.49 \\
\hline 11 & $\begin{array}{l}\text { Which of the following is most likely to cause foodborne illnesses? } \\
\text { Answer: leaving stuffing in a cooked turkey until it cools to room temperature }\end{array}$ & 1 & 0.57 & 0.50 \\
\hline 12 & $\begin{array}{l}\text { What is the safest method for cooling a large pot of hot soup? } \\
\text { Answer: put the soup in a shallow pan and refrigerate it right away }\end{array}$ & 1 & 0.32 & 0.47 \\
\hline Total & & 12 & & \\
\hline
\end{tabular}




\section{TABLE 5. Results from the foods that increase risk of foodborne disease scale}

\begin{tabular}{|c|c|c|c|c|}
\hline \multirow{2}{*}{ Rank } & \multirow{2}{*}{ Questions } & \multirow{2}{*}{$\begin{array}{c}\text { Total } \\
\text { possible } \\
\text { score }\end{array}$} & \multicolumn{2}{|c|}{ Correct answers } \\
\hline & & & Mean & SD \\
\hline 1 & $\begin{array}{l}\text { Eating which of these foods will increase a person's risk of foodborne illnesses? } \\
\text { (Check all that apply) } \\
\text { Answer: Raw oysters, clams, or mussels or rare hamburgers; home-canned beans, } \\
\text { carrots, peas, or potatoes right from the jar; leftover soup reheated until warm, but not } \\
\text { boiling; grilled steak served on the same plate that held raw steak without washing the } \\
\text { plate; cooked shellfish that have unopened shells; sliced melon; foods prepared in a } \\
\text { kitchen with a pet present; picnic foods that were stored at room temperature for }>2 \mathrm{~h}\end{array}$ & 8 & 4.79 & 2.18 \\
\hline 2 & $\begin{array}{l}\text { Chilling or freezing eliminates harmful germs in food. } \\
\text { Answer: false }\end{array}$ & 1 & 0.76 & 0.43 \\
\hline 3 & $\begin{array}{l}\text { Which food is least likely to cause foodborne illnesses? } \\
\text { Answer: chocolate cake that was left on the kitchen counter overnight }\end{array}$ & 1 & 0.54 & 0.50 \\
\hline Total & & 10 & & \\
\hline
\end{tabular}

\section{TABLE 6. Results from the groups at greatest risk for foodborne disease scale}

\begin{tabular}{|c|c|c|c|c|}
\hline \multirow{2}{*}{ Rank } & \multirow{2}{*}{ Questions } & \multirow{2}{*}{$\begin{array}{c}\text { Total } \\
\text { possible } \\
\text { score }\end{array}$} & \multicolumn{2}{|c|}{ Correct answers } \\
\hline & & & Mean & SD \\
\hline 1 & $\begin{array}{l}\text { Compared to most people, which of these individuals are more likely to get sick or } \\
\text { seriously ill from harmful germs in food? (Check all that apply) } \\
\text { Answer: preschool children, pregnant women, older people, people who are HIV } \\
\text { positive, cancer patients }\end{array}$ & 5 & 3.71 & 1.63 \\
\hline 2 & $\begin{array}{l}\text { People should be especially careful about not eating raw seafood if they have: } \\
\text { Answer: all of the above }\end{array}$ & 1 & 0.78 & 0.41 \\
\hline Total & & 6 & & \\
\hline
\end{tabular}




\begin{tabular}{|c|c|c|c|c|}
\hline \multirow{2}{*}{ Rank } & \multirow{2}{*}{ Questions } & \multirow{2}{*}{$\begin{array}{c}\text { Total } \\
\text { possible } \\
\text { score }\end{array}$} & \multicolumn{2}{|c|}{ Correct answers } \\
\hline & & & Mean & SD \\
\hline 1 & $\begin{array}{l}\text { Salmonella bacteria cause foodborne illnesses and are commonly found in chicken, } \\
\text { turkey, or eggs. How can these food items be made safe? } \\
\text { Answer: cook them thoroughly }\end{array}$ & 1 & 0.85 & 0.36 \\
\hline 2 & $\begin{array}{l}\text { Trichinosis is most likely associated with which food? } \\
\text { Answer: raw or undercooked pork }\end{array}$ & 1 & 0.67 & 0.47 \\
\hline 3 & $\begin{array}{l}\text { You may contaminate the food you touch with Salmonella bacteria if you don't wash your } \\
\text { hands after touching: } \\
\text { Answer: raw chicken }\end{array}$ & 1 & 0.64 & 0.48 \\
\hline 4 & $\begin{array}{l}\text { Harmful E. coli bacteria are most likely associated with which food? } \\
\text { Answer: raw or undercooked beef }\end{array}$ & 1 & 0.60 & 0.49 \\
\hline 5 & $\begin{array}{l}\text { Botulism is a disease that is most likely associated with: } \\
\text { Answer: canned foods }\end{array}$ & 1 & 0.57 & 0.50 \\
\hline 6 & $\begin{array}{l}\text { Staph (Staphylococcus) bacteria that cause foodborne illnesses are most likely associated with: } \\
\text { Answer: food prepared by cooks with their bare hands and then left at room temperature }\end{array}$ & 1 & 0.27 & 0.45 \\
\hline 7 & $\begin{array}{l}\text { Campylobacter bacteria are most likely associated with which food? } \\
\text { Answer: raw or undercooked poultry }\end{array}$ & 1 & 0.14 & 0.34 \\
\hline 8 & $\begin{array}{l}\text { Listeria bacteria are most likely associated with: } \\
\text { Answer: deli meats }\end{array}$ & 1 & 0.12 & 0.33 \\
\hline Total & & 8 & & \\
\hline
\end{tabular}

to be offered prior to camping, campers might more often use standard food safety practices, which might then reduce the incidence of foodborne illnesses during camping activities.

\section{Food safety knowledge and age}

No significant differences in overall food safety knowledge were found among the age groups $(P>0.05)$ (Table 9$)$, that is, the total number of correct responses did not significantly differ. However, campers in the 26- to 35-year age range had the highest mean food safety knowledge score in four of the six categories, although these differences were not significant. However, the 46- to 55-year age group had a significantly higher mean score $(P<0.05)$ on knowledge in time and temperature category than did the youngest camper group. These results indicated that the 26- to 35-year-old campers had a slight advantage in food safety knowledge in most categories, which may be helpful information for educators when developing food safety education materials.

\section{Food safety knowledge and ethnicity}

A significant difference in food safety knowledge was found based on ethnicity (Table 9). Respondents who identified as Caucasian had the highest knowledge scores $(20.99 \pm 4.04)$ $(F(3,256)=4.16, P<0.01)$. Respondents who identified as Hispanic often incorrectly answered the questions specifically related to identifying foods that increase the risk of foodborne illnesses and common food pathogens.

\section{Food safety knowledge and educational background}

Significant differences in food safety knowledge were found based on the educational background of participants (Table 9). Respondents with some graduate or professional work appeared to be overall more knowledgeable regarding food safety than were respondents with less education. Respondents with a high school diploma or less had the lowest food safety scores $(18.50 \pm 3.54)$ followed by respondents with a high school diploma $(19.38 \pm 3.48)$, 


\section{TABLE 8. t-tests of food safety knowledge for gender and previous training}

\begin{tabular}{l|c|c|c}
\hline \multirow{2}{*}{ Variable } & \multicolumn{2}{|c}{ Mean $(\mathrm{SD})$} & $t$ value \\
\hline Gender & Female $(\mathrm{n}=175)$ & Male $(\mathrm{n}=87)$ & $t(260)$ \\
\hline Overall knowledge $^{a}$ & $21.43(4.13)$ & $19.86(3.89)$ & $-2.95^{* *}$ \\
\hline Time and temp. & $8.61(1.76)$ & $8.38(1.66)$ & -1.026 \\
\hline Cross-contamination & $5.86(1.61)$ & $5.14(1.61)$ & -3.406 \\
\hline Risky group & $1.43(0.74)$ & $1.44(0.70)$ & 0.086 \\
\hline Groups at risk & $1.24(0.66)^{*}$ & $1.02(0.63)^{*}$ & $-2.545^{* *}$ \\
\hline Common pathogens & $4.29(1.64)$ & $3.89(1.62)$ & -1.897 \\
\hline Food safety training & YES $(\mathrm{n}=38)$ & $\mathrm{NO}(\mathrm{n}=227)$ & $t(263)$ \\
\hline Overall knowledge & $22.37(4.38)$ & $20.61(4.03)$ & $2.46^{*}$
\end{tabular}

${ }^{a}$ Each correct answer received one point.

${ }^{*} P<0.05$

${ }^{* *} P<0.01$

some college ( $20.21 \pm 4.08)$, a bachelor's degree ( 21.05 $\pm 4.24)$, and a graduate or professional degree ( 21.68 $\pm 4.24)$. Campers with bachelor's, graduate, and/or professional degrees appeared to be better able to identify common pathogens found in different types of foods. These results indicate that camping food safety knowledge may be impacted by education level; campers at a higher education level seem to be more knowledgeable about food safety topics.

\section{Food safety knowledge and self-reported practice}

The present study was also designed to evaluate the association between food safety knowledge and food safety practice. Participants' food safety knowledge had a weak but positive correlation with food safety self-reported practice $(r=0.19, P$ $<0.05$ ) (Table 10), which indicates that increases in campers' food safety knowledge and training may lead to improved camping food safety practice compliance. For instance, if campers were trained in the causes of foodborne illnesses prior to camping, this increase in knowledge might result in better compliance with food safety practices and a likely decrease in the risk of foodborne illnesses during camping.

\section{Food safety knowledge and other variables}

The one-way ANOVA revealed no significant relationship between food safety knowledge and the number of times respondents camped within a year $(P>0.05)$, that is, camping frequency did not impact food safety knowledge. The length of each camping event also did not influence food safety knowledge $(P>0.05)$ (data not shown in the table).
Independent $t$-tests were conducted evaluate the differences in food safety knowledge and practices between campers who had or had not experienced foodborne illnesses. Campers with foodborne illness experience (21.63 $\pm 3.40)$ and those without such experience $(20.70 \pm 4.24)$ did not differ significantly on levels of food safety knowledge $(t(263)=1.398, P=0.08)$. Campers with foodborne illness experience $(3.59 \pm 0.38)$ and those without such experience $(3.60 \pm 0.44)$ also did not differ significantly in food safety practices $(t(243)=-0.156, P=0.20)$. Campers with food service work experience $(21.17 \pm 4.01)$ and without such work experience $(20.76 \pm 4.16)$ did not significantly differ in levels of knowledge $(t(263)=0.697, P=0.86)$. Campers with food service work experience $(3.66 \pm 0.40)$ and those without such work experience $(3.59 \pm 0.44)$ also did not differ significantly in terms of their food safety practices $(t(243)=1.169, P=0.45)$.

\section{DISCUSSION}

The present study was focused on evaluation and assessment of the food safety knowledge of campers in the United States. The results confirmed that more food safety education should be provided and may be beneficial to campers for improving their food safety knowledge prior to camping and thus lowering the risk of foodborne illness. Because few studies have been conducted on food safety among campers, these results have practical implication for enhancing food safety knowledge among campers.

The majority of study respondents were women who can be classified as middle-age to elderly from working to lower middle class backgrounds. The participants did not appear 
to be knowledgeable about groups of individuals who are particularly susceptible to foodborne illnesses, such as elderly people, young children, and people with compromised immune systems. They also could not identify common food pathogens that can increase the risk of foodborne disease. Because poor personal hygiene practices among food handlers pose a serious risk of foodborne illness (11), campers should know how to safely cook and handle food for groups of individuals at highest risk. Participants also did not often avoid foods that increase the risk of food poisoning. For instance, participants did not understand what types of leftover food could seriously increase the risk of foodborne illness outbreaks. This finding was especially important because viruses and bacterial pathogens are responsible for the majority of foodborne illnesses (11). Fung and Menon (11) found that foodborne pathogens are the leading cause of most severe foodborne illnesses. Thus, campers should learn about different types of foods associated with different foodborne pathogens. This knowledge is especially important for those who participate in group camping. Camping programs should provide educational workshops addressing outdoor cooking, the consequences of unsafe food practices, awareness of groups at high risk, and common food pathogens.

Although food safety knowledge did not significantly differ by age, except for identifying groups at greatest risk, the results revealed significant gender effects on food safety knowledge during camping; women were more knowledgeable than men. Women typically prepare more meals and have more experience in safe food handling practices compared with men (3), although men are increasingly preparing meals and may cook more meals during camping. Food safety educators could develop training modules for camping food safety that emphasize the areas in this study in which knowledge was lacking. Novice campers should be encouraged to take a food safety training course, especially at summer camps for high-risk groups, such as immunocompromised children.

Significant differences were found in the level of food safety knowledge by ethnicity and education. Respondents identifying as Caucasian were more likely to correctly identify proper food safety practices than were other ethnic groups, such as Asian, American Indian, and Latino. Nevertheless, the North American Camping Report (19) indicated an increase in the number of non-Caucasian campers in the United States as more people seek outdoor activities such as camping; half of newest campers identified as Asian, African American, and Hispanic. The demographic profile of participants in the present study may not have been diverse enough to capture the camping experiences of other ethnic groups. Hence, the results could change if these experiences were elaborated. In the present study, campers with a high school diploma or less were less likely to understand camping food safety than were campers with higher education levels. Campers with higher education were more likely to know which behaviors are required to prevent foodborne outbreaks. This finding could reflect an increase in the number of young campers (Generation Z, those individuals born from 1995 to 2005), as supported by North American Camping Report statistics $(18,19)$. Thus, food safety education and training for campers is needed that can target multiple generations and can be translated into bilingual materials to reach various ethnic groups. Food safety training should be required for campers prior to camping.

A camper who receives training regarding food safety while camping will have an increased level of food safety knowledge $(3,18)$. Because more people are willing to try tent camping, van camping, or camping in cabins (19), campers should be provided with information and guidelines to safely cook and prepare foods while camping, which should translate into food safety practices and a reduction in the number of foodborne illnesses. The USDA (37) also asserted that when food is not handled correctly foodborne illness can occur. Food safety during camping includes keeping hot and cold foods at the correct temperature, cleaning utensils, preventing cross-contamination, drinking safe water, using a thermometer, and using soap or disposable wipes. Outdoor food safety educators could develop flyers or e-brochures in multiple languages targeting various nationalities with diverse educational backgrounds to promote the importance of attending food safety training programs. These programs could specifically encourage campers identifying as nonCaucasian who have a high school diploma or less to participate in such programs because in our study these groups had the least camping food safety knowledge. Flyers and brochures are eye catching, can be used as promotional tools to deliver information, and can be effective for strategic persuasion $(20,43)$. Younger people may prefer to obtain information about food safety programs through online platforms or social media, such as YouTube and Facebook (12). Teenagers may prefer social media, whereas older people may prefer written materials. A survey of campers could help determine whether they desire to learn more about camping food safety and which combination of online educational materials might be most effective.

According to the ACA (3), studies have been conducted to monitor trends and issues related to health, safety, and camping programs to ensure that campers are not affected by unsafe food practices. The results of the present study suggest that campers can practice food safety more effectively when they have more knowledge. The ACA (2) has been monitoring the number of illnesses and injuries that occur during camping and have identified risk factors associated with illnesses. The results of the present study also support the development of prevention strategies to help campers improve their overall camping experience and increase their knowledge of food safety. Because food safety practices are followed by increased knowledge, campers must be educated 


\section{TABLE 9. One-way ANOVA for participants' age, ethnicity, and educational level}

\begin{tabular}{|c|c|c|c|c|c|c|c|}
\hline Age Variable (yr) & $\begin{array}{c}18-25 \\
(n=17)\end{array}$ & $\begin{array}{l}26-35 \\
(n=8)\end{array}$ & $\begin{array}{c}36-45 \\
(n=15)\end{array}$ & $\begin{array}{c}46-55 \\
(n=36)\end{array}$ & $\begin{array}{c}56-65 \\
(n=126)\end{array}$ & $\begin{array}{c}66+ \\
(n=54)\end{array}$ & $F$ value \\
\hline \multicolumn{8}{|l|}{ Mean (SD) } \\
\hline 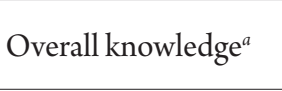 & $18.40(5.40)$ & $22.88(3.76)$ & $20.53(4.63)$ & $21.67(4.69)$ & $21.02(3.97)$ & $20.54(3.60)$ & $\begin{array}{c}F(255) \\
1.96^{*}\end{array}$ \\
\hline Time and temp. & $7.35(2.12)^{*}$ & $8.88(1.96)$ & $7.73(2.02)$ & $8.94(1.84)^{*}$ & $8.52(1.68)$ & $8.59(1.43)$ & $\begin{array}{c}F(250) \\
2.710^{*}\end{array}$ \\
\hline Cross-contamination & $5.47(2.07)$ & $6.25(1.28)$ & $5.67(2.02)$ & $6.00(1.57)$ & $5.53(1.66)$ & $5.48(1.56)$ & $\begin{array}{c}F(250) \\
0.775\end{array}$ \\
\hline Risky food & $1.06(1.03)$ & $1.63(0.52)$ & $1.27(0.80)$ & $1.33(0.72)$ & $1.48(0.69)$ & $1.52(0.67)$ & $\begin{array}{c}F(250) \\
1.584\end{array}$ \\
\hline Groups at risk & $1.29(0.77)$ & $1.13(0.64)$ & $1.53(0.52)$ & $1.36(0.68)$ & $1.14(0.67)$ & $1.02(0.60)$ & $\begin{array}{c}F(250) \\
2.284\end{array}$ \\
\hline Common pathogens & $3.24(1.30)$ & $5.00(1.77)$ & $4.33(1.88)$ & $4.03(1.84)$ & $4.35(1.58)$ & $3.93(1.58)$ & $\begin{array}{c}F(250) \\
2.171\end{array}$ \\
\hline
\end{tabular}

Ethnicity

\begin{tabular}{l|c|c|c|c|c|c|}
\hline & $\begin{array}{c}\text { Non- } \\
\text { Vispanic } \\
\text { Variable }\end{array}$ & $\begin{array}{c}\text { Asian-Pacific } \\
\text { Islander } \\
(n=249)\end{array}$ & $\begin{array}{c}\text { Native } \\
\text { American } \\
(n=2)\end{array}$ & $\begin{array}{c}\text { Hispanic/ } \\
\text { Latino } \\
(n=3)\end{array}$ & F value & \\
\hline
\end{tabular}

Mean (SD)

\begin{tabular}{l|c|c|c|c|c|l}
\hline Overall knowledge & $20.99(4.04)$ & $19.33(4.37)$ & $21.5(4.95)$ & $13.00(3.46)$ & $\begin{array}{c}F(259) \\
4.156^{* *}\end{array}$ & \\
\hline Time and temp. & $8.57(1.71)$ & $7.5(1.87)$ & $9.00(0.00)$ & $6.00(1.73)$ & $\begin{array}{c}F(256) \\
2.995^{*}\end{array}$ & \\
\hline Cross-contamination & $5.62(1.66)$ & $5.50(1.38)$ & $5.00(1.41)$ & $4.33(2.89)$ & $\begin{array}{c}F(256) \\
2.580^{*}\end{array}$ & \\
\hline Risky food & $1.45(0.71)^{*}$ & $1.17(0.75)$ & $1.00(1.41)$ & $0.33(0.57)^{*}$ & $\begin{array}{c}F(256) \\
2.988\end{array}$ & \\
\hline Groups at risk & $1.18(0.66)$ & $1.00(0.89)$ & $1.50(0.71)$ & $0.67(0.58)$ & $\begin{array}{c}F(256) \\
0.679\end{array}$ & \\
\hline Common pathogens & $4.17(1.60)^{*}$ & $4.16(2.14)$ & $5.00(1.41)$ & $1.67(1.53)^{*}$ & $\begin{array}{c}F(256) \\
0.903\end{array}$ & \\
\hline
\end{tabular}

Educational level

\begin{tabular}{l|c|c|c|c|c|c|c|c}
\hline Variable & $1(n=2)$ & $2(n=29)$ & $3(n=78)$ & $4(n=62)$ & $5(n=20)$ & $6(n=71)$ & $F$ value \\
\hline $\begin{array}{l}\text { Mean (SD) } \\
\text { Overall knowledge }\end{array}$ & $18.5(3.54)$ & $19.38(3.48)$ & $20.21(4.08)$ & $21.05(4.24)$ & $22.45(3.52)$ & $21.68(4.24)$ & $\begin{array}{c}F(261) \\
2.524^{*}\end{array}$ \\
\hline Time and temp. & $7.50)(2.12)$ & $8.13(1.68)$ & $8.47(1.76)$ & $8.53(1.72)$ & $8.85(1.60)$ & $8.63(1.76)$ & $\begin{array}{c}F(256) \\
0.639\end{array}$ \\
\hline Cross-contamination & $5.50(0.71)$ & $5.83(1.56)$ & $5.39(1.76)$ & $5.63(1.60)$ & $5.95(1.54)$ & $5.69(1.70)$ & $\begin{array}{c}F(256) \\
0.588\end{array}$ \\
\hline
\end{tabular}




\section{TABLE 9. One-way ANOVA for participants' age, ethnicity, and educational level (cont.)}

\begin{tabular}{|c|c|c|c|c|c|c|c|}
\hline Age Variable (yr) & $\begin{array}{l}18-25 \\
(n=17)\end{array}$ & $\begin{array}{l}26-35 \\
(n=8)\end{array}$ & $\begin{array}{l}36-45 \\
(n=15)\end{array}$ & $\begin{array}{c}46-55 \\
(n=36)\end{array}$ & $\begin{array}{c}56-65 \\
(n=126)\end{array}$ & $\begin{array}{c}66+ \\
(n=54)\end{array}$ & $F$ value \\
\hline \multicolumn{8}{|l|}{ Mean $(S D)$} \\
\hline Risky food & $1.50(0.71)$ & $1.14(0.69)$ & $1.45(0.70)$ & $1.37(0.72)$ & $1.45(0.70)$ & $1.54(0.69)$ & $\begin{array}{c}F(256) \\
1.373\end{array}$ \\
\hline Groups at risk & $1.50(0.71)$ & $1.21(0.56)$ & $1.06(0.62)$ & $1.18(0.74)$ & $1.40(0.60)$ & $1.20(0.67)$ & $\begin{array}{c}F(256) \\
1.148\end{array}$ \\
\hline Common pathogens & $2.50(2.12)$ & $3.07(1.62)^{*}$ & $3.85(1.52)$ & $4.34(1.63)^{*}$ & $4.80(1.61)^{*}$ & $4.62(1.50)^{*}$ & $\begin{array}{c}F(256) \\
5.975\end{array}$ \\
\hline
\end{tabular}

${ }^{a}$ Each correct answer received one point.

${ }^{*} P<0.05$

${ }^{* *} P<0.01$

1, less than high school or GED; 2, high school or GED; 3, some college; 4, bachelor's degree;

5 , some graduate/professional work; 6 , graduate or professional degree.

\section{TABLE 10. Correlations between food safety knowledge and self-reported practice}

\begin{tabular}{l|c|c}
\hline Variable & 1 & 2 \\
\hline 1. Knowledge & -- & $.189^{* *}$ \\
\hline 2. Practice & $.189^{* *}$ & -- \\
\hline${ }^{* *} P<.01$ & \multicolumn{2}{|c}{} \\
\hline
\end{tabular}

prior to going on a camping trip. Consistent with the reports from $\operatorname{ACA}(2,3)$, campers should participate in a systematic safety training program to learn the benefits of adhering to food safety practices during camping, even at a young age. Thus, camping staff should be thoroughly trained so certified staff can transfer skills and knowledge to campers at the site. Staff may also attend an intervention program or educational session to help determine which areas or activities should be thoroughly presented to campers preparing foods for themselves (3).

Although we found no significant associations between food safety knowledge and camping time or length of stay, specific guidelines related to food safety during camping should be provided upon arrival at campsites. Camping trips may last a weekend, a week, or longer (15). Campsites often become a substitute for the home, where campers sleep, eat, and socialize (8). For overnight camping, safe food handling practices are needed for keeping foods either hot without a heat source or cold without a refrigerator throughout the stay at a campsite (35). A campsite can provide a pamphlet that provides accurate information about aspects campers should pay particular attention to when preparing and cooking meals.

In this study, food safety knowledge and self-reported practices did not differ between individuals who had experienced foodborne illness and those who had not. Although the affected campers were aware of foodborne illness symptoms, they were not relatively more knowledgeable about safe handling and cooking of foods during camping. Thus, ongoing food safety education is needed. Food service work experience also did not lead to enhanced food safety knowledge and actual practices. This finding suggests that food safety training was not properly provided to employees or that skills learned did not transfer to outdoor activities. Food service operations may lack educational programs and training for their workers with methods and materials that can be easily applied in other food safety situations. Demonstrations by experts can help identify development needs for employees by emphasizing task-specific responsibilities to improve current knowledge (29). Thus, demonstrations or job shadowing may 
be most effective because they provide food handlers direct experience with how to properly handle foods and information about various food safety criteria.

\section{CONCLUSION}

The present study revealed a lack of food safety knowledge among campers in the United States and that food handling behaviors of these campers could be improved. The findings also revealed specific areas in which campers' knowledge should be augmented. Campers need instruction in safe food handling practices for preparing and serving foods to people that are at a higher risk of foodborne illness, in preventing food poisoning, and in identifying food pathogens. The level of food safety knowledge and use of correct food safety practices differed among campers by gender, ethnicity, and education level. Because of these differences, food safety training should be more frequently provided to specific demographic groups who are less knowledgeable about food safety practices during camping. A positive relationship was found between campers' food safety knowledge during camping and their previous food safety training experience, suggesting that if more training were provided to campers, their food safety knowledge would probably improve. Another important finding was the need for food safety knowledge and training to be combined, ultimately leading to adherence to food safety practices during camping. In the United States, campers should be effectively educated about safe food handling practices for preparing and handling foods while camping, which would result in a reduced number of foodborne outbreaks and illness cases at campsites.

\section{FUTURE STUDIES}

Limitations in the present study could be addressed in future studies. First, the data were collected only in the United States and may not represent the entire global camping population. Future studies could include validation of these results with campers in other countries. Second, the sample size in each ethnic group was small. Future research could focus on exploring the difference in food safety practices among multicultural campers through direct observation of safe food handling practices. Cultural differences can be included in future studies to examine perceptions and knowledge levels among campers from different cultures. A hands-on teaching component that helps campers reinforce safe food handling behaviors once knowledge is gained could be evaluated through experiments.

\section{ACKNOWLEDGMENT}

This study was sponsored by the College of Applied and Natural Sciences, Louisiana Tech University.

\section{REFERENCES}

1. Adventure Nation. 2013. What is camping. Available at: http://www.adventurenation. com/activity/camping. Accessed 10 December 2019.

2. American Camp Association. 2010. The healthy camp study impact report 2006 2010. Available at: https://www.acacamps. org/sites/default/files/downloads/HealthyCamp-Study-Impact-Report.pdf. Accessed 15 November 2020.

3. American Camp Association. 2019. 2019 Impact report. Available at: https://www. acacamps.org/sites/default/files/page documents/about/2019-ACA-Annual-ImpactReport.pdf. Accessed 30 January 2020.

4. Armus, T. 2020. Norovirus outbreak hits Yosemite National Park, with 170 suffering symptoms. The Washington Post. Available at: https://www.washingtonpost.com/ nation/2020/01/17/yosemite-norovirusoutbreak/. Accessed 13 February 2020.

5. Centers for Disease Control and Prevention 2018. National Outbreak Reporting System (NORS). Available at: https://wwwn.cdc.gov/ norsdashboard/. Accessed 11 November 2019.

6. Centers for Disease Control and Prevention 2019. Histoplasmosis outbreak at Louisiana campsite: CDC partners with state health department to respond. Available at: https:// www.cdc.gov/ncezid/dfwed/stories/ louisiana-histoplasmosis-outbreak.html. Accessed 10 November 2019.
7. Centers for Disease Control and Prevention. 2020. Foodborne germs and illnesses. Available at: https://www.cdc.gov/ foodsafety/foodborne-germs.html. Accessed 1 April 2020

8. Coleman Company and Outdoor Foundation. 2017. 2017 American camper report. Available at: https://outdoorindustry. org/wp-content/uploads/2015/03/2017Camping-Report FINAL.pdf. Accessed 14 December 2019.

9. Evans, E. W., and E. C. Redmond. 2019. Older adult consumers' attitudes and perceptions of risk, control, and responsibility for food safety in the domestic kitchen. J. Food Prot. 82:371-378.

10. Frewer, L. 2004. The public and effective risk communication. Toxicol. Lett. 149:391-397.

11. Fung, F., and S. Menon. 2018. Food safety in the 21 st century. Biomed. J. 41:88-95.

12. Gibson, K., and S. Trnka. 2020. Young people's priorities for support on social media: "It takes trust to talk about these issues." Comput. Human Behav. 102:238-247.

13. Griffith, C. J., D. Worsfold, and R. Mitchell. 1998. Food preparation, risk communication and the consumer. Food Control 9:225-232.

14. Hardy, A., D. Hanson, and U. Gretzel. 2012. Online representations of RVing neo-tribes in the USA and Australia. J. Tour. Cult. Change 10:219-232.
15. Hogue, M. 2011. A short history of the campsite. The Design Observer Group. Available at: http://places.designobserver com/ ... /a-short-history-of-the-campsite. Accessed 18 November 2019.

16. Jirasek, I., D. N. Roberson, and M. Jiraskova. 2017. The impact of families camping together: opportunities for personal and social development. Leis. Sci. 39:79-93.

17. Kampgrounds of American. 2016. New, multicultural generation of campers. Available at: http://www.koapressroom. com/press/new-multicultural-generationof-campers-benefitting-from-time-spentoutdoors/. Accessed 23 November 2019.

18. Kampgrounds of American. 2018. North American camping report. Available at: https://koa.com/north-american-campingreport/. Accessed 3 January 2020.

19. Kampgrounds of American. 2019. North American camping report. Available at: https://koa.com/north-american-campingreport/. Accessed 10 January 2020.

20. Ladd, A. D. 2010. Developing effective marketing materials: brochure design considerations. J. Cent. Profit. Agric. 8:1-3.

21. Lehmann, D. R., S. Gupta, and J. Seckel. 1997. Market research. Addison-Wesley, Reading, MA. 
22. Marklinder, I., M. Magnusson, and M. Nydahl. 2013. Chance: a healthy lifestyle in terms of food handling and hygiene. Br. Food J. 115:223-234.

23. Miles, S., D. S. Braxton, and L. J. Frewer. 1999. Public perceptions about microbiological hazards in food. Br. Food J. 101:744-762.

24. Miles, S., and V. Scaife. 2003. Optimistic bias and food. Nutr. Res. Rev. 16:3-19.

25. Milton, A., and B. Mullan. 2010. Consumer food safety education for the domestic environment: a systematic review. Br. Food J. 112:1003-1022.

26. Neff, R. A., M. Spiker, C. Rice, A. Schklair, S. Greenberg, and B. E. Leib. 2019. Misunderstood food date labels and reported food discards: a survey of U.S. consumer attitudes and behaviors. Waste Manag. 86:123-132.

27. Neuman, J. 2004. Education and learning through outdoor activities. Available at: https://www.salto-youth.net/downloads/ toolbox tool download-file-973/Sample Education_Learning_Through_Outdoor Activities_for\%20printer with $\% 20$ cropmarks.pdf. Accessed 15 December 2019.

28. Painter, J. A., R. M. Hoekstra, T. Ayers, R. V. Tauxe, C. R. Braden, F. J. Angulo, and P. M. Griffin. 2013. Attribution of foodborne illnesses, hospitalizations, and deaths to food commodities by using outbreak data, United States, 1998-2008. Emerg. Infect. Dis. 19:407-415.

29. Rony, Z. T., F. M. Lubis, and A. Rizkyta. 2019. Job shadowing as one of the effective activities in the promotion process creates quality managers. Int. J. Recent Technol. Eng. 8:388-396.
30. Schirick, E. 2015. Strategies for managing the risks of food contamination and communicable disease at camp. American Camp Association. Available at: https:// www.acacamps.org/resource-library/ camping-magazine/strategies-managingrisks-food-contamination-communicabledisease-camp. Accessed 22 November 2019.

31. Statista. 2019. Number of youth participants in camping in the United States from 2006 to 2017 (in millions). Available at: https:// www.statista.com/statistics/190671/ youth-participants-in-camping-in-the-ussince-2006/. Accessed 4 December 2019.

32. Statista. 2019. Share of Americans who went camping in the last 12 months in 2018, by age. Available at: https://www.statista.com/ statistics/227417/number-of-campers-usa/. Accessed 20 November 2019.

33. Terpstra, M. J., L. P. A. Steenbekkers, N. C. M. Maertelaere, and S. Nijhuis. 2005. Food storage and disposal: consumer practices and knowledge. Br. Food J. 107:526-533.

34. Thaivalappil, A., I. Young, C. Paco, A. Jeyapalan, and A. Papadopoulos. 2020. Food safety and the older consumer: systematic review and meta-regression of their knowledge and practices at home. Food Control 107:1-13.

35. U.S. Department of Agriculture. 2011. Food safety while hiking, camping \& boating. Available at: https://www.fsis.usda. gov/shared/PDF/Food_Safety_While Hiking_Camping_Boating.pdf. Accessed 21 November 2019.

36. U.S. Department of Agriculture. 2017. Food safety education. Available at: https:// www.fsis.usda.gov/wps/portal/fsis/topics/ food-safety-education/get-answers/foodsafety-fact-sheets/foodborne-illness-anddisease/foodborne-illness-peaks-in-summer. Accessed 1 May 2020.
37. U.S. Food and Drug Administration. 2016. Foodborne illnesses: what you need to know. Available at: https://www.fsis.usda. gov/wps/wcm/connect/602fab29-2afd4037-a75d-593b4b7b57d2/Foodborne Illness_What_Consumers_Need to_Know. pdf?MOD=AJPERES. Accessed 10 December 2019.

38. U.S. Food and Drug Administration. 2020. Outbreaks of foodborne illness. Available at: https://www.fda.gov/food/ recalls-outbreaks-emergencies/outbreaksfoodborne-illness. Accessed 20 March 2020.

39. Vainio, A., J. Kaskela, E. Finell, S. Ollila, and J. Lunden. 2020. Consumer perceptions raised by the food safety inspection report: does the smiley communicate a food safety risk? Food Control 110:1-8.

40. Wills, W. J., A. Meah, A. M. Dickinson, and F. Short. 2015. "I don't think I ever had food poisoning." A practice-based approach to understanding foodborne disease that originates in the home. Appetite 85:118-125.

41. Worsfold, D. 1997. Food safety behavior in the home. Br. Food J. 99:97-104.

42. Zhong, Y., S. Y. Lin, M. H. Huang, C. C. Chen, and C. H. Chien. 2017. Exploring the relationships among campers' leisure motive, satisfaction and campsite service innovation. Int. J. Organ. Innov. 10:220-232.

43. Zhou, Z. 1997. Destination marketing: measuring the effectiveness of brochures. J. Travel Tour Market. 6:143-158. 